\title{
Estrogen Upregulates Cyclooxygenase-1 Gene Expression in Ovine Fetal Pulmonary Artery Endothelium
}

\author{
Sandy S. Jun, Zhong Chen, Margaret C. Pace, and Philip W. Shaul \\ Department of Pediatrics, University of Texas Southwestern Medical Center at Dallas, Dallas, Texas 75235-9063
}

\begin{abstract}
Prostacyclin $\left(\mathrm{PGI}_{2}\right)$ is a key mediator of pulmonary vasodilation in the perinatal period and its synthesis in the pulmonary vasculature increases markedly during late gestation due to enhanced expression of the rate-limiting enzyme cyclooxygenase-1 (COX-1). The hormone estrogen may play a role in COX-1 upregulation since fetal estrogen levels rise dramatically during late gestation and estrogen enhances $\mathrm{PGI}_{2}$ synthesis in nonpulmonary vascular cells. We therefore studied the direct effects of estrogen on COX-1 expression in ovine fetal pulmonary artery endothelial cells (PAEC). Exposure to estradiol-17 $\beta\left(\mathrm{E}_{2} \beta, 10^{-10}\right.$ to $\left.10^{-6} \mathrm{M}\right)$ caused a dose-related increase in COX-1 mRNA expression that was evident after $48 \mathrm{~h}$ and maximal at $10^{-8} \mathrm{M}$ (fourfold increase). COX-1 mRNA stability was unchanged, suggesting that the upregulation is mediated at the level of transcription. $\mathrm{E}_{2} \beta$ treatment $\left(10^{-8} \mathrm{M}\right.$ for $\left.48 \mathrm{~h}\right)$ also caused a threefold increase in COX-1 protein expression and a threefold increase in $\mathrm{PGI}_{2}$ synthesis stimulated by bradykinin, the calcium ionophore A23187, or arachidonic acid. The estrogen receptor (ER) antagonist ICI 182,780 fully reversed the effects of the hormone on COX-1 protein expression and on arachidonic acid-stimulated $\mathrm{PGI}_{2}$ synthesis, and ER expression was evident in the PAEC by immunoblot analysis. These findings indicate that physiologic levels of estrogen cause upregulation of COX-1 expression and $\mathrm{PGI}_{2}$ synthesis in fetal PAEC via activation of PAEC ER. This process may play a critical role in optimizing the capacity for $\mathrm{PGI}_{2}$-mediated pulmonary vasodilation at birth, and it may also be involved in estrogen responsiveness in other vascular beds. $(J$. Clin. Invest. 1998. 102:176-183.) Key words: estrogen receptor $\bullet$ immunoblotting $\bullet$ polymerase chain reaction $\bullet$ prostacyclin $\bullet$ pulmonary circulation
\end{abstract}

\section{Introduction}

Prostacyclin $\left(\mathrm{PGI}_{2}\right)^{1}$ and other vasodilator prostaglandins are important mediators of pulmonary vascular and parenchymal function in the perinatal period. $\mathrm{PGI}_{2}$ infusion causes pulmo-

Address correspondence to Philip W. Shaul, Department of Pediatrics, University of Texas Southwestern Medical Center, 5323 Harry Hines Blvd., Dallas, TX 75235-9063. Phone: 214-648-2015; FAX: 214648-2481; E-mail: pshaul@mednet.swmed.edu

Received for publication 17 October 1997 and accepted in revised form 21 April 1998.

J. Clin. Invest.

(c) The American Society for Clinical Investigation, Inc. 0021-9738/98/07/0176/08 \$2.00

Volume 102, Number 1, July 1998, 176-183

http://www.jci.org nary vasodilation in the fetus and newborn, and the inhibition of endogenous $\mathrm{PGI}_{2}$ synthesis leads to pulmonary vasoconstriction and marked attenuation of the fall in pulmonary vascular resistance at birth $(1,2)$. There is also evidence that $\mathrm{PGI}_{2}$ modulates vascular cell growth in the pulmonary circulation (3). In addition, endogenous prostaglandins are important stimulators of surfactant synthesis and cell differentiation in the developing lung (4). $\mathrm{PGI}_{2}$ is the primary prostaglandin produced in the developing pulmonary vasculature, where the main site of synthesis is the endothelium (5).

Studies in several species have shown that $\mathrm{PGI}_{2}$ synthesis in the whole lung increases dramatically during late gestation (68). In experiments with lambs, we have previously demonstrated that $\mathrm{PGI}_{2}$ synthesis in intrapulmonary arteries rises markedly during late fetal life, and that this is due to a developmental increase in the expression of the rate-limiting enzyme for $\mathrm{PGI}_{2}$ synthesis, cyclooxygenase (COX) (5). In particular, we have shown that there is a maturation-related increase in the expression of the type 1 isoform of COX, or COX-1 (5).

The mechanism underlying the developmental increase in COX-1 abundance in the fetal pulmonary vasculature is unknown. Upregulation during late fetal life suggests that it is due to a factor which has increasing activity in the lung during late gestation. One potential factor is the hormone estrogen, which increases markedly in abundance in fetal plasma during this period due to rising production by the placenta (9-11). Previous studies have shown that prolonged estrogen exposure enhances $\mathrm{PGI}_{2}$ production in nonpulmonary vascular cells (12, 13). However, it is not known whether estrogen modulates COX-1 expression, or whether the hormone alters $\mathrm{PGI}_{2}$ synthesis in fetal pulmonary vascular cells.

To better understand the basic mechanisms regulating COX-1 expression in the fetal pulmonary circulation, the present investigation was designed to determine the direct effects of estrogen on COX-1 in fetal pulmonary artery endothelial cells (PAEC). Experiments were performed in early passage, cultured ovine fetal PAEC, which we have used previously in studies of oxygen modulation of COX-1 expression (14). Based on the observation that pulmonary arterial COX-1 expression increases in sheep during late gestation while fetal plasma estrogen levels are rising $(5,9-11)$, and the finding that prolonged estrogen exposure enhances $\mathrm{PGI}_{2}$ synthesis in certain nonpulmonary vascular cells $(12,13)$, we hypothesized that estrogen upregulates COX-1 expression in ovine fetal PAEC. In addition to testing this hypothesis, studies were performed to answer the following questions: (a) Is COX-1 expression modified by estrogen at physiologic concentrations? (b) What is the mechanism(s) underlying the effects of estrogen on COX-1? (c) Are there resulting changes in $\mathrm{PAEC} \mathrm{PGI}_{2}$

1. Abbreviations used in this paper: $\mathrm{COX}$, cyclooxygenase; $\mathrm{E}_{2} \beta$, estradiol-17 $\beta$; MDH, malate dehydrogenase; PAEC, pulmonary artery endothelial cell; $\mathrm{PGI}_{2}$, prostacyclin; RT, reverse transcription. 
synthesis? And $(d)$ what is the role of estrogen receptors (ER) in this process?

\section{Methods}

Cell culture and treatment. PAEC were obtained from mixed breed fetal lambs at $125-135 \mathrm{~d}$ gestation, with term being $144 \pm 4 \mathrm{~d}$, using methods that we have previously described (14). The PAEC were propagated in RPMI-1640 medium containing 10\% iron-supplemented calf serum, $10 \%$ lamb serum, $1 \%$ L-glutamine, $1 \%$ antibioticantimycotic mixture, $0.15 \%$ nystatin, $0.15 \%$ gentamycin, and $0.10 \%$ tylosin, in a humidified incubator with $5 \% \mathrm{CO}_{2}$ in air at $37^{\circ} \mathrm{C}$. The identity of the cells was confirmed by phenotype (cobblestone appearance and contact inhibition), by immunofluorescence studies with antibody to factor VIII-related antigen, and by examination of acetylated low density lipoprotein uptake. The cells were studied at passage 4-6.

Near-confluent PAEC were placed in phenol red-free, serum-free media for $12 \mathrm{~h}$ to remove the effects of the estrogen-like activity of phenol red and serum-derived estrogen. The cells were then placed in phenol red-free media containing $20 \%$ charcoal-stripped serum. The charcoal stripping removes estrogen metabolites and other steroid hormones (15). The cells were treated for up to $96 \mathrm{~h}$ with either control media or media containing varying concentrations of estradiol$17 \beta\left(E_{2} \beta\right)$ ranging from $10^{-10}$ to $10^{-6} \mathrm{M}$. Culture media was replaced every $48 \mathrm{~h}$ and estrogen treatment was repeated every $24 \mathrm{~h}$.

Reverse transcription-polymerase chain reaction ( $R T-P C R)$ assay. A semiquantitative RT-PCR assay was established to evaluate COX-1 mRNA abundance in PAEC because the mRNA was not detectable in PAEC by Northern analysis of poly A(+) RNA. Total cellular RNA was obtained from control and estrogen-treated PAEC grown in $75-\mathrm{cm}^{2}$ flasks by a single extraction method with an acid guanidinium thiocyanate-phenol-chloroform mixture (16). RT was performed by methods previously reported using $5 \mu \mathrm{g}$ of total RNA (16). Briefly, cDNA synthesis was carried out using 200-U Maloney murine leukemia virus reverse transcriptase, $5 \mu \mathrm{M}$ oligo-(dT), $1 \mathrm{mM}$ deoxyribonucleoside triphosphate (dNTP), and $3 \mathrm{mM} \mathrm{Mg}^{2+}$ in a volume of $20 \mu \mathrm{l}$. In selected tubes the reverse transcriptase was omitted to control for amplification from contaminating cDNA or genomic DNA. The temperature profile was: $(a)$ annealing at room temperature $\left(25^{\circ} \mathrm{C}\right)$ for $5 \mathrm{~min},(b)$ extension at $42^{\circ} \mathrm{C}$ for $45 \mathrm{~min}$, and $(c)$ termination at $99^{\circ} \mathrm{C}$ for $5 \mathrm{~min}$.

PCR was performed on the resulting RT product using specific oligonucleotide primers for sheep COX-1 (17). The sequence of the sense primer was $5^{\prime}$-ATGAGTACCGCAAGAGGTTTGG-3' and that of the antisense primer was 5'-ACGTGGAAGGAGACATAGG-3'. The PCR reactions contained $1.5 \mathrm{mM} \mathrm{Mg}^{2+}, 1-\mu \mathrm{M}$ primers, $200-\mu \mathrm{M}$ dNTPs, reaction buffer, and $5 \mu \mathrm{l}$ cDNA in a final volume of $50 \mu \mathrm{l}$. To minimize nonspecific amplification, a "hot start" procedure was used in which the PCR tubes were placed in a thermal cycler (480; Perkin-Elmer Cetus Corp., Emeryville, CA) prewarmed to $94^{\circ} \mathrm{C}$. After $2 \mathrm{~min}$, each tube was opened sequentially and $2.5 \mathrm{U}$ (in $0.25 \mu \mathrm{l})$ Taq DNA polymerase was added. The PCR temperature profile consisted of 30 cycles of $94^{\circ} \mathrm{C}$ for $45 \mathrm{~s}$ (denaturation), $57^{\circ} \mathrm{C}$ for $45 \mathrm{~s}$ (annealing), and $72^{\circ} \mathrm{C}$ for $1 \mathrm{~min}$ (extension) followed by an additional $5 \mathrm{~min}$ final extension at $72^{\circ} \mathrm{C}$. The primer location, primer concentration, $\mathrm{Mg}^{2+}$ concentration, and annealing temperature were optimized to produce the greatest amount of a single PCR product.

The PCR products were size fractionated by agarose gel electrophoresis. The identity of the PCR products was confirmed, and they were quantitated by transferring the DNA to nylon filters, probing with a ${ }^{32} \mathrm{P}$ end-labeled internal oligonucleotide primer specific for sheep COX-1, and performing densitometric analysis on the resulting autoradiographs. PCR product identity was also confirmed by direct double-stranded sequencing. To control for the RT step and RNA stability, RT-PCR was also done for the housekeeping gene malate dehydrogenase $(\mathrm{MDH})$ using published oligonucleotide primer se- quences (18). The PCR temperature profile for MDH was identical to that described above for COX-1.

Preliminary experiments were performed to determine the relationship between the quantity of total RNA subjected to RT-PCR and the amount of PCR product generated. Linear regression analysis showed high correlations between densitometry values for RT-PCR products and the quantity of total RNA used for COX-1 RT-PCR $(r=0.95-0.99, n=3$ experiments $)$ and for MDH RT-PCR $(r=0.96-$ $0.99, n=3)$. We have previously used RT-PCR assays done in this semiquantitative manner in studies of pulmonary endothelial nitric oxide synthase expression; Northern analyses were performed in parallel with RT-PCR assays, and identical results were obtained with the two techniques $(16,19)$. To evaluate COX-1 mRNA stability, additional RT-PCR experiments were done using cells treated with 25 $\mu \mathrm{g} / \mathrm{ml}$ actinomycin D for varying time periods up to $2 \mathrm{~h}$.

Immunoblot analysis. To quantitate the levels of $\mathrm{COX}-1$ protein expression in control and $\mathrm{E}_{2} \beta$-treated cells, immunoblot analysis was performed using methods that generally followed those we have previously reported (14). PAEC cells were harvested in ice-cold PBS, pelleted, resuspended in $50 \mathrm{mM}$ Tris buffer ( $\mathrm{pH} 7.4$ ) containing $16 \mathrm{mM}$ CHAPS, $100 \mathrm{mM} \mathrm{NaCl}, 0.5 \mathrm{mM}$ EDTA, $0.02 \mathrm{mM}$ EGTA, $0.4 \mathrm{mM}$ $\beta$-mercaptoethanol, $1.6 \mathrm{mM}$ dithiothreitol, and $2 \mu \mathrm{g} / \mathrm{ml}$ each of soybean trypsin inhibitor, limabean trypsin inhibitor, antipain, and leupeptin, and ultrasonically disrupted (Branson Ultrasonics, Chicago, IL). The protein contents of the preparations were determined, SDSpolyacrylamide gel electrophoresis was performed on equivalent protein samples with $10 \%$ acrylamide, and the proteins were electrophoretically transferred to PVDF membranes. The membranes were blocked overnight in buffer containing $137 \mathrm{mM} \mathrm{NaCl}$ and $20 \mathrm{mM}$ Tris (pH 7.5) with $0.5 \%$ Tween- 20 and $5 \%$ dried milk, and were incubated with 1:100 COX-1 antiserum (Oxford Biomedical Research, Inc., Oxford, MI) for $2 \mathrm{~h}$ at room temperature. After incubation with primary antiserum, the membranes were washed with the $137-\mathrm{mM} \mathrm{NaCl}$ buffer with Tween-20 at $0.2 \%$ and dried milk at $0.2 \%$ and incubated for $1 \mathrm{~h}$ with a 1:10,000 dilution of anti-rabbit Ig antibody horseradish peroxidase conjugate raised in donkey. The membranes were washed in the 137-mM NaCl buffer with Tween-20, and the band for COX-1 was visualized by chemiluminescence (ECL Western Blotting Analysis System, Amersham Corp., Arlington Heights, IL) and quantitated by densitometry. Purified COX-1 protein (Cayman Chemical Co., Ann Arbor, MI) was used as a positive control. Similar techniques, including the use of a positive control, were used to evaluate COX-2 protein expression. To determine the role of estrogen receptor (ER) activation in the effects of the hormone on COX protein expression, additional studies were performed in cells treated with the ER antagonist ICI $182,780\left(10^{-5} \mathrm{M}\right)(20)$.

To determine if ER protein is expressed in the ovine fetal PAEC, immunoblot analysis was also performed using $2 \mu \mathrm{g} / \mathrm{ml}$ of the mouse monoclonal antibody AER 320 directed against amino acids 495-595 in the estrogen-binding domain of human ER $\alpha$ (Neomarkers, Inc., Fremont, CA). Since the ligand-binding domains of the classical ER $\alpha$ isoform and the newly described ER $\beta$ isoform are highly homologous $(21,22)$, the antisera may recognize either receptor subtype.

Incubations for prostaglandin synthesis. Control and estrogentreated PAEC grown in 24-well plates were preincubated for $15 \mathrm{~min}$ in a humidified incubator at $37^{\circ} \mathrm{C}$ with $500 \mu$ l of phenol red-free RPMI-1640 media added per well. The preincubation media was replaced with fresh RPMI-1640 media and 30-90-min incubations were performed. At the end of the incubation, the media was placed into ice-cold tubes containing $100 \mu \mathrm{g}$ of acetylsalicylic acid and stored at $-20^{\circ} \mathrm{C}$ until the time of assay for $\mathrm{PGI}_{2}$. We have previously demonstrated that under these conditions the $\mathrm{PGI}_{2}$ measured is newly synthesized (14).

In experiments designed to determine the reaction in the $\mathrm{PGI}_{2}$ synthetic cascade that is modified by estrogen exposure, selected wells were incubated in phenol red-free RPMI-1640 media alone, indicative of basal (nonstimulated) synthesis, and others were treated with agents that activate the synthetic pathway at various steps. Incu- 
bations were performed in the presence of bradykinin to assess $\mathrm{PGI}_{2}$ synthesis stimulated by receptor-mediated mobilization of arachidonic acid from phospholipids (23). Incubations with the calcium ionophore A23187 were performed to evaluate $\mathrm{PGI}_{2}$ synthesis stimulated by an increase in cytosolic-free calcium, which activates arachidonic acid mobilization by a nonreceptor-mediated process (23). In addition, $\mathrm{PGI}_{2}$ synthesis stimulated by exogenous arachidonic acid was also measured to determine if estrogen-mediated changes in synthesis are related to changes in COX activity (23). Preliminary experiments revealed that maximal stimulation of $\mathrm{PGI}_{2}$ synthesis is obtained with bradykinin, A23187, and arachidonic acid at $10^{-5} \mathrm{M}$. Therefore, this concentration was used in all ensuing experiments. Preliminary experiments also showed that basal and stimulated $\mathrm{PGI}_{2}$ synthesis rose linearly with time between 30-90 min of cell incubation. As a result, 60-min incubations were used in all ensuing studies. Additional experiments were performed comparing arachidonic acid-stimulated $\mathrm{PGI}_{2}$ synthesis in control PAEC, estrogen-treated PAEC $\left(10^{-8} \mathrm{M}\right.$ for $\left.48 \mathrm{~h}\right)$, and PAEC treated with both estrogen and ICI $182,780\left(10^{-5} \mathrm{M}\right)$. ICI 182,780 alone had no effect on $\mathrm{PGI}_{2}$ synthesis in control cells. In all experiments, $n=4-6$ for each determination, and findings were replicated in three independent experiments.

Prostaglandin assays. Samples of incubation media were assayed for the stable metabolite of $\mathrm{PGI}_{2}, 6$-keto- $\mathrm{PGF}_{1 \alpha}$, by radioimmunoassay as previously reported (14). Briefly, the assay procedure used duplicate aliquouts of standard $(0-1,000 \mathrm{pg})$ or samples placed into a solution containing $0.1 \mathrm{M}$ phosphate-buffered saline plus $0.1 \%$ polyvinylpyrrolidone (1:1). Antiserum $(0.1 \mathrm{ml} ; 1: 4,000$ titer $)$ and $\left[{ }^{3} \mathrm{H}\right] 6-$ keto-PGF $\mathrm{PG}_{1 \alpha}(0.1 \mathrm{ml} ; 12,000 \mathrm{dpm})$ were added, and the tubes were incubated at $4^{\circ} \mathrm{C}$ for $12-18 \mathrm{~h}$. Bound and free ligand were separated with dextran-coated charcoal, and bound ligand was counted by liquid scintillation spectrometry. The unknown quantities of $\mathrm{PGI}_{2}$ were determined from the standard curves generated.

Statistical analysis. Analysis of variance with Newman-Keuls posthoc testing was used to compare mean values between more than two groups. Nonparametric analysis of variance was used when indicated. Single comparisons between two groups were performed with nonpaired Student's $t$ tests. Significance was accepted at the 0.05 level of probability. All results are expressed as mean \pm SEM.

\section{Results}

$C O X-1 \mathrm{mRNA}$ expression. The effect of varying concentrations of $E_{2} \beta$ on COX-1 mRNA expression in fetal PAEC is shown in Fig. 1. The cells were treated with control media or media with $10^{-10}$ to $10^{-6} \mathrm{M} \mathrm{E}_{2} \beta$ for $48 \mathrm{~h}$. Single PCR products were obtained for COX-1 at the expected size of 355 bp (Fig. 1 $A)$. The representative Southern blot reveals a dose-dependent increase in COX-1 mRNA abundance as determined by RT-PCR in response to $\mathrm{E}_{2} \beta$ treatment. PCR was also performed for $\mathrm{MDH}$ to control for the RT step, yielding a single PCR product at the expected size of $369 \mathrm{bp}$. There was no change in $\mathrm{MDH}$ mRNA abundance with $\mathrm{E}_{2} \beta$ treatment. Quantitative densitometry for three independent experiments confirmed these results (Fig. $1 B$ ). There was a concentrationrelated increase in steady-state COX-1 mRNA levels, with a maximal increase of 4.4-fold at $10^{-8} \mathrm{M} \mathrm{E}_{2} \beta$.

The time course for $\mathrm{E}_{2} \beta$ modulation of COX-1 mRNA expression in fetal PAEC is shown in Fig. 2. In the representative Southern blot (Fig. $2 \mathrm{~A}$ ), COX-1 mRNA abundance as determined by RT-PCR was increased following both 48 and $96 \mathrm{~h}$ of treatment with $10^{-8} \mathrm{M} \mathrm{E}_{2} \beta$ compared with controls. $\mathrm{E}_{2} \beta$ had no effect on MDH mRNA abundance. Quantitative densitometry for three independent experiments confirmed these results, showing a 4.4-fold increase in COX-1 expression at $48 \mathrm{~h}$ and a persistent increase of 4.2 -fold at $96 \mathrm{~h}$ (Fig. $2 \mathrm{~B}$ ). Before

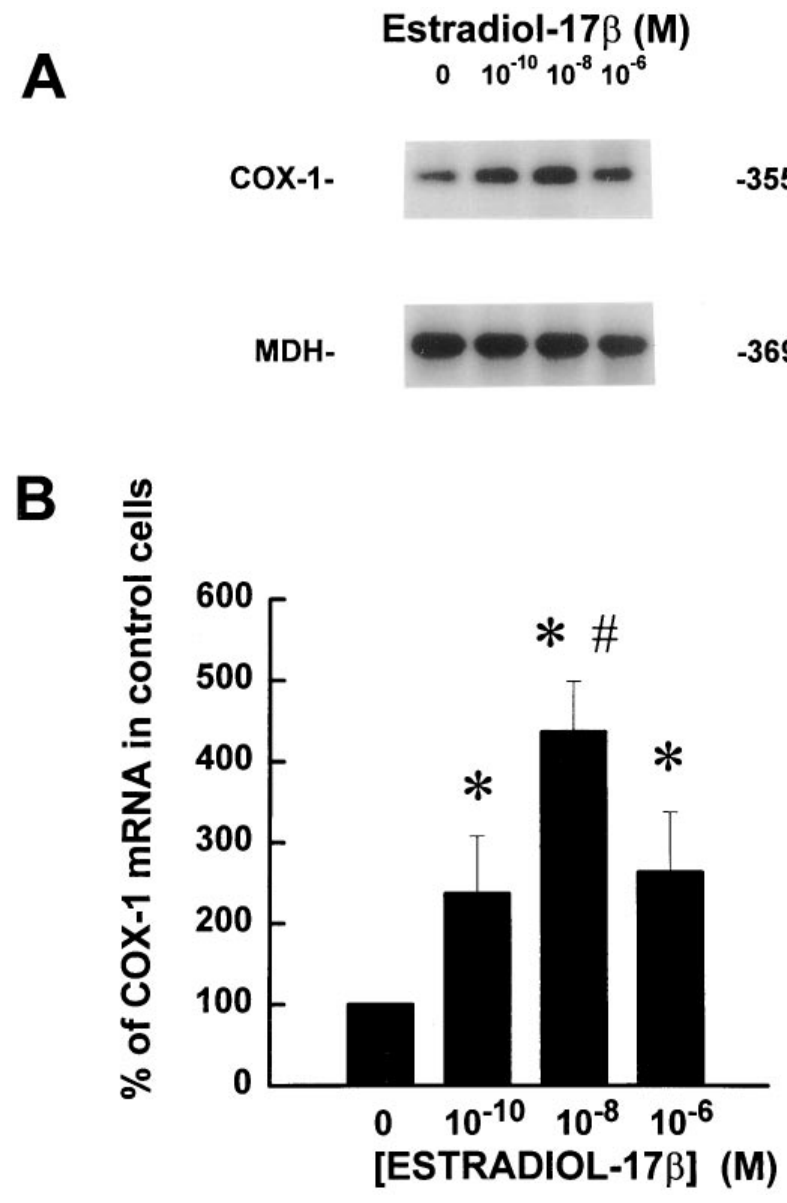

Figure 1. (A) Southern analyses of RT-PCR products for COX-1 (top) and malate dehydrogenase ( $\mathrm{MDH}$, bottom) in fetal PAEC exposed to varying concentrations of $\mathrm{E}_{2} \beta$ for $48 \mathrm{~h}$. Band sizes were: COX-1, 355 bp; MDH, 369 bp. (B) Summary data for three independent experiments. COX-1 densitometry values corrected for MDH are expressed as a percentage in control cells (mean \pm SEM). $* P<$ 0.05 vs control, ${ }^{\#} P<0.05$ vs $10^{-10} \mathrm{M} \mathrm{E}_{2} \beta$.

$48 \mathrm{~h}$ there was no significant change in COX-1 mRNA abundance with exposure to $\mathrm{E}_{2} \beta$ (data not shown).

The effects of $\mathrm{E}_{2} \beta$ on COX-1 mRNA stability are depicted in Fig. 3. RT-PCR was performed on cells treated with control media or media with $10^{-8} \mathrm{M} \mathrm{E}_{2} \beta$ for $48 \mathrm{~h}$, followed by $25 \mu \mathrm{g} / \mathrm{ml}$ actinomycin $\mathrm{D}$ for varying durations up to $2 \mathrm{~h}$. The representative study shown reveals no difference in COX-1 mRNA degradation in control and $\mathrm{E}_{2} \beta$-treated cells. In four independent experiments COX-1 mRNA half-life was similar in control and $\mathrm{E}_{2} \beta$-treated cells, being $2.0 \pm 0.2$ and $2.1 \pm 0.5 \mathrm{~h}$ (mean $\left.\pm \mathrm{SEM}\right)$, respectively.

$C O X$ protein expression. The effects of $\mathrm{E}_{2} \beta$ on $\mathrm{COX}-1$ protein abundance are shown in Fig. 4. In the representative immunoblot shown (Fig. $4 A$ ), COX-1 was increased in cells treated with $10^{-8} \mathrm{M} \mathrm{E}_{2} \beta$ for $48 \mathrm{~h}$, and this effect was completely reversed by ER antagonism with ICI 182,780. The cumulative findings of three independent experiments confirmed these results (Fig. $4 \mathrm{~B}$ ), revealing a 2.7-fold increase in COX-1 protein with $E_{2} \beta$ treatment that was fully negated by ICI $182,780\left(10^{-5} \mathrm{M}\right)$. COX-2 protein was not detected in any study groups (data not shown). 


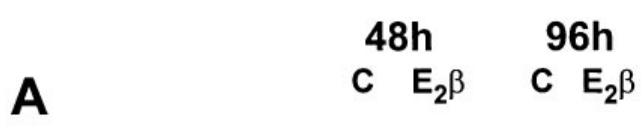

cox-1-
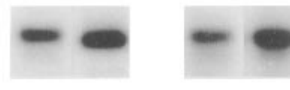

-355 bp

MDH-
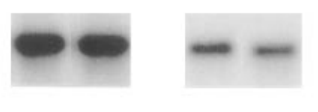

$-369 \mathrm{bp}$

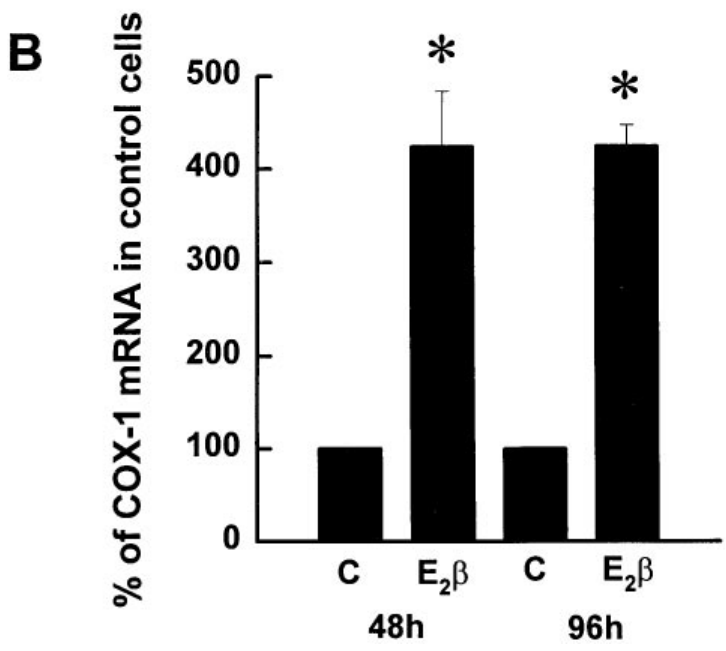

Figure 2. Time course of the effect of estrogen on COX-1 mRNA abundance in fetal PAEC. Cells were exposed to control media $(C)$ or media containing $10^{-8} \mathrm{M} \mathrm{E}_{2} \beta$. (A) Southern analysis of RT-PCR products for COX-1 (top) and MDH (bottom) in control and $\mathrm{E}_{2} \beta$ treated cells. Band sizes were: COX-1, 355 bp; MDH, 369 bp. $(B)$ Summary data for three independent experiments. COX-1 densitometry values corrected for $\mathrm{MDH}$ are expressed as a percentage in control cells (mean \pm SEM). ${ }^{*} P<0.05$ vs control.

$\mathrm{PGI}_{2}$ synthesis. The effect of $\mathrm{E}_{2} \beta$ on basal and bradykininstimulated $\mathrm{PGI}_{2}$ synthesis in fetal PAEC is shown in Fig. $5 \mathrm{~A}$. $\mathrm{PGI}_{2}$ synthesis was measured in control and $\mathrm{E}_{2} \beta$-treated cells $\left(10^{-8} \mathrm{M}\right.$ for $\left.48 \mathrm{~h}\right)$ during 60 -min incubations. In control cells, basal $\mathrm{PGI}_{2}$ synthesis was $10.6 \pm 1.4 \mathrm{pg} / \mathrm{well}$, and synthesis was stimulated 2.4-fold by bradykinin. Prolonged $\mathrm{E}_{2} \beta$ treatment caused a $64 \%$ increase in basal $\mathrm{PGI}_{2}$ synthesis, and a 2.9 -fold increase in bradykinin-stimulated synthesis. The effect of $\mathrm{E}_{2} \beta$ on A23187- and arachidonic acid-stimulated $\mathrm{PGI}_{2}$ synthesis is depicted in Fig. 5 B. In parallel with the estrogen-mediated increases in basal and bradykinin-stimulated production, synthesis with A23187 was increased by 2.7 -fold and synthesis with arachidonic acid was increased by 2.5 -fold after exposure to $10^{-8} \mathrm{M} \mathrm{E}_{2} \beta$ for $48 \mathrm{~h}$.

Role of estrogen receptors. To further determine the role of ER in the response to $E_{2} \beta$, arachidonic acid-stimulated $\mathrm{PGI}_{2}$ synthesis was compared in control cells, cells treated with $10^{-8} \mathrm{M} \mathrm{E}_{2} \beta$ for $48 \mathrm{~h}$, and cells treated with $\mathrm{E}_{2} \beta$ plus the ER antagonist ICI $182,780\left(10^{-5} \mathrm{M}\right)$. Similar to the findings shown in Fig. $5 \mathrm{~B}$, estrogen caused a 2.3 -fold increase in arachidonic acid-stimulated $\mathrm{PGI}_{2}$ synthesis compared to control conditions (Fig. 6). This effect was completely reversed by ER antagonism. To determine if ER protein is expressed in the ovine fetal PAEC, immunoblot analysis was performed. Immunoblots revealed signal for ER protein at $67 \mathrm{kD}$ (Fig. 6, inset). Similar observations were made in three independent experiments.

\section{Discussion}

In the present study, we have evaluated the effects of $E_{2} \beta$ on COX-1 expression in cultured ovine fetal PAEC, enabling us to examine the direct effects of the hormone on the fetal pulmonary endothelium without potential secondary effects due to changes in cardiac or systemic vascular function $(24,25)$. We have demonstrated that $\mathrm{E}_{2} \beta$ causes a marked upregulation in COX-1 mRNA expression in the ovine fetal pulmonary artery endothelium. To our knowledge, this is the first demonstration of a direct effect of estrogen on COX-1 expression in any cell type.

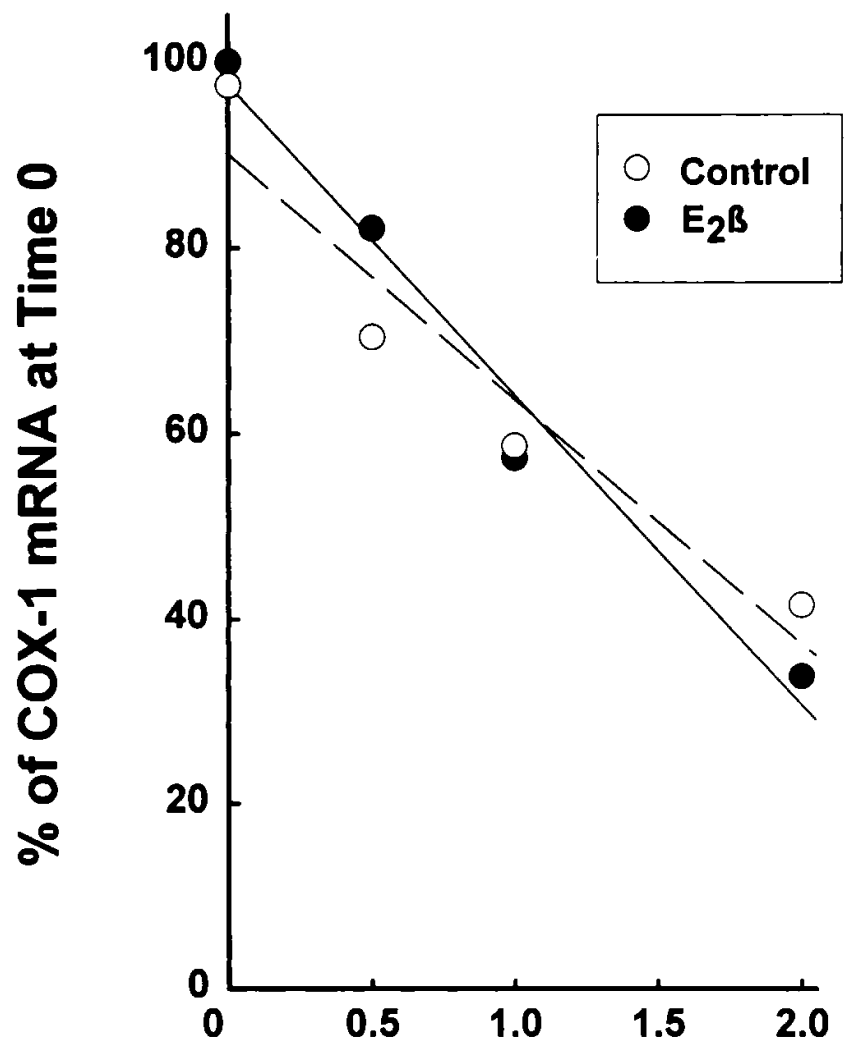

Figure 3. Effect of estrogen on COX-1 mRNA stability. Cells were treated with control media (open symbol, dashed line) or media containing $10^{-8} \mathrm{M} \mathrm{E}_{2} \beta$ for $48 \mathrm{~h}$ (closed symbol, solid line), followed by 25 $\mu \mathrm{g} / \mathrm{ml}$ actinomycin $\mathrm{D}$ for varying time periods up to $2 \mathrm{~h}$. COX-1 mRNA abundance, assessed by RT-PCR, is expressed as a percent at time 0 of actinomycin D. Linear regression analysis yielded $r=-0.95$ for control cells and $r=-0.99$ for $\mathrm{E}_{2} \beta$-treated cells. Similar findings were obtained in four independent experiments. 
A

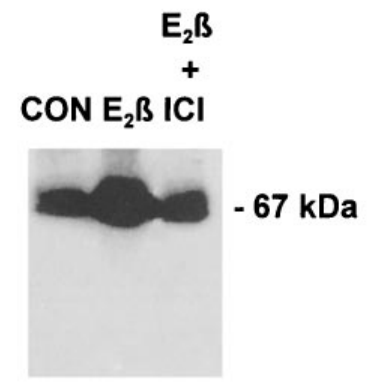

B

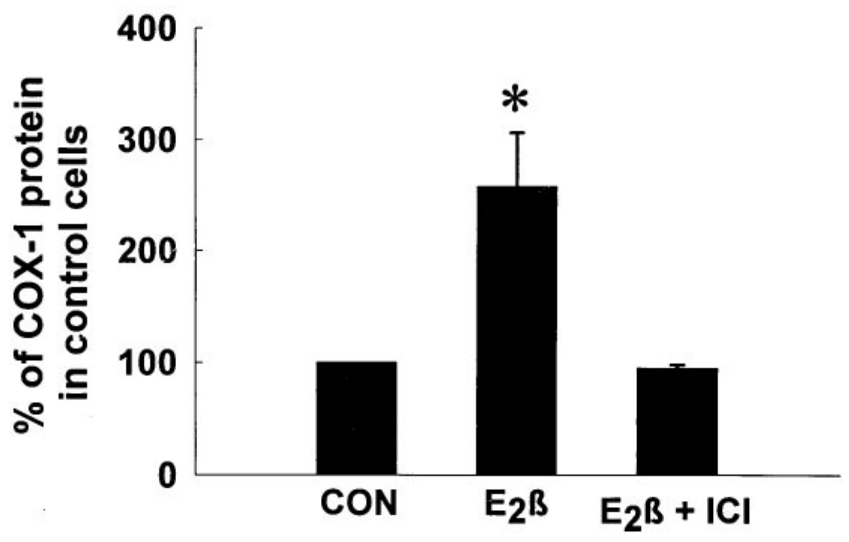

Figure 4. Effect of estrogen on COX-1 protein abundance evaluated by immunoblot analysis. Cells were exposed to control media $(C O N)$, media containing $10^{-8} \mathrm{M} \mathrm{E}_{2} \beta$, or media containing $\mathrm{E}_{2} \beta$ plus ICI $182,780\left(10^{-5} \mathrm{M}\right)$ for $48 \mathrm{~h}$. COX-1 protein was detected at $70 \mathrm{kD}$. The immunoblots shown are representative of three independent experiments. Summary data for quantitative densitometry for the three experiments is given in $B$. Mean \pm SEM values are depicted for protein abundance expressed as a percentage in control cells. $* P<0.05$ vs control.

We have also shown that the effect of estrogen on COX-1 mRNA occurs at a threshold concentration of $10^{-10} \mathrm{M}$, and that there is maximal upregulation by more than fourfold at $10^{-8} \mathrm{M}$. This indicates that the effect of the hormone occurs at levels that are achieved in the fetal plasma in a variety of species during late gestation (9-11). For example, plasma levels of unconjugated estradiol in fetal sheep increase fivefold from 80 to $140 \mathrm{~d}$ gestation $($ term $=144 \mathrm{~d})$, reaching concentrations in the range of $10^{-9} \mathrm{M}(9)$. In addition, we have shown that the effect of $\mathrm{E}_{2} \beta$ on COX-1 mRNA is evident by $48 \mathrm{~h}$ and persists for at least $96 \mathrm{~h}$. This time course is consistent with prior studies examining the direct effect of chronic estrogen exposure on $\mathrm{PGI}_{2}$ synthesis in nonpulmonary vascular cells. In both piglet aortic endothelium and rat aortic smooth muscle cells, $\mathrm{PGI}_{2}$ synthesis is enhanced after 2-3 d of exposure to $10^{-9} \mathrm{M} \mathrm{E}_{2} \beta$ $(12,13)$. This suggests that COX-1 expression is regulated by prolonged exposure to physiologic concentrations of the hormone in a variety of vascular cells in addition to the fetal pulmonary endothelium. Furthermore, we have demonstrated in the fetal PAEC that COX-1 mRNA stability is not altered by prolonged $E_{2} \beta$ exposure, suggesting that the chronic effects of the hormone on COX-1 are mediated at the level of gene transcription. These findings contrast with those of Myers et al., who demonstrated enhanced $\mathrm{PGI}_{2}$ synthesis in rat aortic endothelium after only 60 min exposure to $E_{2} \beta$ that was not due to changes in $\mathrm{COX}$ or $\mathrm{PGI}_{2}$ synthase abundance (26). Cumulatively, these observations suggest that there may be both chronic and acute effects of the hormone on the $\mathrm{PGI}_{2}$ synthetic cascade that are related to different mechanisms. In addition to the experiments examining COX-1 mRNA abundance, we performed studies evaluating the effect of $\mathrm{E}_{2} \beta$ on $\mathrm{COX}-1$ protein expression. After exposure to $10^{-8} \mathrm{M} \mathrm{E}_{2} \beta$ for $48 \mathrm{~h}, \mathrm{COX}-1$ protein was increased by 2.7 -fold, paralleling the rise in COX-1 mRNA. In contrast to the findings for COX-1, COX-2 protein was not detected in either control or $\mathrm{E}_{2} \beta$-treated cells, revealing that the effects of $\mathrm{E}_{2} \beta$ on $\mathrm{COX}-1$ are unique to that isoform.

Along with the studies of COX-1 expression, we determined whether there are resulting changes in endothelial cell $\mathrm{PGI}_{2}$ synthesis. After treatment with $10^{-8} \mathrm{M} \mathrm{E}_{2} \beta$ for $48 \mathrm{~h}$,
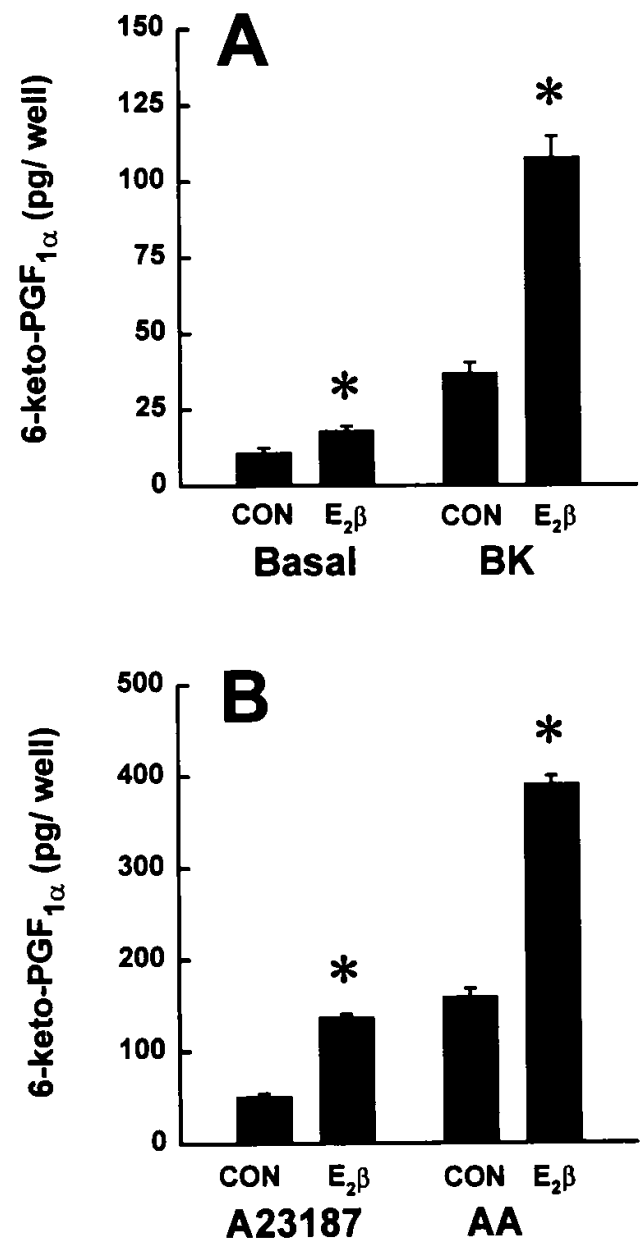

Figure 5. Effect of estrogen on basal and stimulated $\mathrm{PGI}_{2}$ synthesis in fetal PAEC. Cells were exposed to control media $(\mathrm{CON})$ or media containing $10^{-8} \mathrm{M} \mathrm{E}_{2} \beta$ for $48 \mathrm{~h}$ and then incubated for $60 \mathrm{~min}$ in the absence of exogenous stimulation (Basal) or in the presence of bradykinin $(B K)(A)$, or in the presence of $\mathrm{A} 23187$ or arachidonic acid

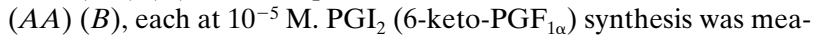
sured by RIA. Values are mean \pm SEM, $n=4-6$. $* P<0.05$ vs control. 


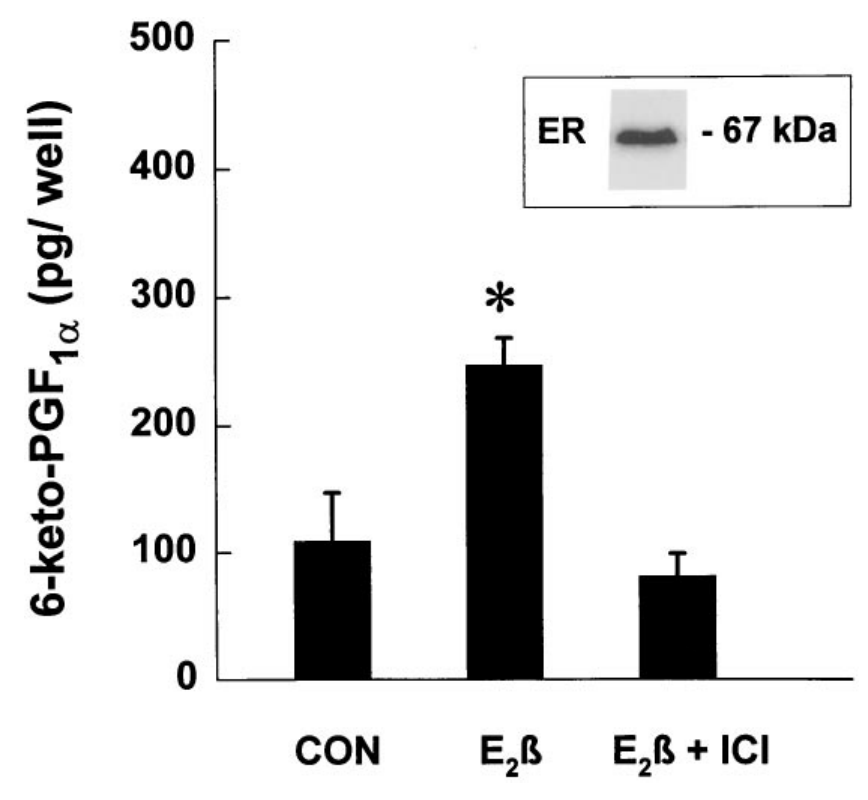

Figure 6. Role of estrogen receptors in the effect of $\mathrm{E}_{2} \beta$ on COX activity. Cells were exposed to control media $(C O N)$, media containing $10^{-8} \mathrm{M} \mathrm{E}_{2} \beta$, or media containing $\mathrm{E}_{2} \beta$ plus ICI $182,780\left(10^{-5} \mathrm{M}\right)$ for $48 \mathrm{~h}$ and then incubated for $60 \mathrm{~min}$ in the presence of $10^{-5} \mathrm{M}$ arachidonic acid. $\mathrm{PGI}_{2}\left(6-\right.$ keto- $\left.P G F_{1 \alpha}\right)$ synthesis was measured by RIA. Values are mean \pm SEM, $n=4-6$. $* P<0.05$ vs control. (Inset) Immunoblot analysis for ER protein in ovine fetal PAEC. Signal for ER protein was evident at $67 \mathrm{kD}$. Results are representative of three independent experiments.

basal $\mathrm{PGI}_{2}$ production was increased by $64 \%$, and synthesis stimulated with bradykinin and A23187 were increased 2.9and 2.7-fold, respectively. In a similar manner, synthesis in the presence of excess exogenous arachidonic acid was augmented 2.5-fold after estrogen treatment, indicating that the effect of estrogen on $\mathrm{PGI}_{2}$ production is not mediated by changes in the capacity for arachidonic acid mobilization. Instead, these results reflect an enhancement in COX enzymatic activity, and this is in agreement with the observation that estrogen augments COX-1 mRNA and protein expression.

In the present investigation, we also determined whether ER are involved in the effect of the hormone on COX-1 protein expression and $\mathrm{PGI}_{2}$ synthesis. The ER antagonist ICI 182,780 fully inhibited the estrogen-mediated increases in both COX-1 protein expression and arachidonic acid-stimulated $\mathrm{PGI}_{2}$ synthesis indicative of the level of COX activity, revealing that ER activation is necessary for these effects. In addition, ER protein expression was demonstrated by immunoblot analysis. These findings indicate that functional ER are expressed in the fetal PAEC, and that they play a key role in the regulation of COX-1. However, it is not yet clear which ER subtype is involved. The $\mathrm{ER} \alpha$ and ER $\beta$ subtypes, which are known to function as transcription factors, are highly homologous, particularly in the DNA-binding domain (95-96\%) and in the $\mathrm{COOH}$-terminal hormone-binding domain (55-58\%) $(21,22)$. In addition, both $\mathrm{ER} \alpha$ and $\mathrm{ER} \beta$ are inhibited by ICI compounds $(20,21)$, and the immunoblot analysis may recognize either $\mathrm{ER} \alpha$ or ER $\beta$. Thus, the observed effects of estrogen on PAEC COX-1 expression may be mediated by either $\mathrm{ER} \alpha, \mathrm{ER} \beta$, or both receptor subtypes, or by a yet unknown
ER subtype. Studies of ER subtype in adult rat lung reveal the expression of both $\mathrm{ER} \alpha$ and $\mathrm{ER} \beta$, with the latter subtype predominating (27), but the pulmonary cell specificity of ER subtype expression is yet to by determined. Further studies are now warranted to distinguish the role of $E R \alpha$ and $E R \beta$ in COX-1 regulation in the pulmonary endothelium.

The present studies suggest that the principal effects of prolonged ER activation on COX-1 expression in the fetal PAEC occur at the level of gene transcription. Although the $5^{\prime}$ flanking region of COX-1 does not contain a canonical TATA box typical of transcriptionally regulated genes, there are putative transcription factor-binding sites that may be highly relevant to estrogen-mediated regulation of COX-1 expression. There are four potential polyomavirus enhancer activator 3 , or PEA3, promoter elements $(28,29)$. PEA3, which belongs to the Ets family of transcription factors, is principally upregulated by the MAP kinase signal transduction pathway (30). Since estrogen is a potent activator of the MAP kinase pathway in a variety of cell types $(31,32)$, it is plausible that the hormone may upregulate COX-1 in the PAEC through MAP kinase and PEA3. In addition, the 5' flanking region of COX-1 contains four copies of the estrogen response element (ERE) half-palindromic motif, GGTCA, or its reverse complement, within 2,100 bp of the translation start codon (28, 29). Many estrogen-regulated promoters do not contain perfect palindromic EREs, but include one or more GGTCA motifs, which are sometimes widely spaced (33-35). As such, the four ERE halfpalindromes should also be considered as potential regulatory elements involved in the modulation of COX-1 expression by the hormone. An investigation of the transcriptional transactivation of COX-1 by estrogen is now indicated to further elucidate the underlying mechanisms.

A degree of caution may be warranted in the direct extrapolation of the present findings in the cultured cells to processes in the intact fetal lung. However, the use of the cultured cells allows us to evaluate the direct effects of single factors such as estrogen on PAEC phenotype, thereby avoiding potential secondary changes resulting from known cardiac and systemic effects of the hormone $(24,25)$. In addition, we have previously demonstrated in parallel studies of intrapulmonary arterial segments and early passage PAEC from newborn lambs that the effects of oxygen on COX-1 expression are conserved in culture (14). Furthermore, more recent studies of COX-1 expression in ovine fetal and newborn intrapulmonary arteries and early passage PAEC have shown that the developmental increase in COX-1 expression is also conserved in the cultured cells (Shaul, P.W., and T.S. Brannon, manuscript submitted for publication). Thus, the ovine fetal PAEC provide an excellent model for the study of the regulation of COX-1 gene expression, and the observed effect of estrogen on COX-1 expression and $\mathrm{PGI}_{2}$ synthesis in the cultured cells may indeed reflect events occurring in the intact fetal lung.

Keeping these potential limitations in mind, there are important physiological implications of estrogen-mediated regulation of pulmonary endothelial COX-1 expression in both the adult and the fetus. In an adult rat model of chronic hypoxic pulmonary hypertension, Rabinovitch et al. found that the disease is much milder in female versus male animals (36). The present observations suggest that this may be due to enhanced COX-1 gene expression related to the effects of estrogen on the pulmonary endothelium in the adult females. In the fetus, estrogen-mediated effects on COX-1 expression may at least 
partially explain the developmental increase in pulmonary COX-1 expression that occurs during late gestation, at a time when fetal plasma estrogen levels are increasing dramatically due to enhanced placental production of the hormone $(5,9)$. We have now demonstrated that physiologic concentrations of $E_{2} \beta$ upregulate COX-1 expression in the fetal pulmonary artery endothelium. This process may be critically involved in optimizing the capacity for $\mathrm{PGI}_{2}$-mediated pulmonary vasodilation at birth.

There are also potential pathophysiologic implications of the present findings, particularly in the fetal lung. In a model of intrauterine infection induced with group B streptococcus in fetal rhesus monkeys, the normal rise in plasma estrogen which occurs before birth is absent (37). In addition, estrogen levels are greatly reduced in the cord blood of postmature human newborns (38). These observations suggest that in pregnancies complicated by placental dysfunction such as that associated with intrauterine infection or postmaturity, diminished estrogen synthesis by the placenta may lead to dimished fetal pulmonary COX-1 expression and impaired pulmonary $\mathrm{PGI}_{2}$ synthesis, thereby contributing to the pathogenesis of persistent pulmonary hypertension of the newborn.

The observed hormonal regulation of COX-1 in the PAEC also has important implications on estrogen-mediated effects in other vascular beds. Studies have shown that $\mathrm{PGI}_{2}$ synthesis increases dramatically in the uterine circulation during pregnancy and that this is not due to increased availability of the substrate arachidonic acid (39). This may instead be related to effects of estrogen on COX-1 gene expression since Moonen et al. determined that there is significantly greater COX enzyme in pregnant versus nonpregnant human myometrium (40). In the coronary circulation, the risk of vascular disease in premenopausal women is very low compared to men, it increases markedly after menopause, and it diminishes again with estrogen replacement therapy after menopause $(41,42)$. These findings may also be related to estrogen-mediated effects on prostaglandin production because $\mathrm{PGI}_{2}$ synthesis is significantly decreased in isolated arteries from postmenopausal versus premenopausal women (43), and $\mathrm{PGI}_{2}$ is critically important as a vasodilator and an inhibitor of thrombosis and platelet aggregation (44). Thus, estrogen-mediated upregulation of COX-1 may play a major role in the function of not only the developing pulmonary circulation, but also the uterine and coronary circulation. Further studies of estrogen-mediated regulation of COX-1 gene expression in fetal PAEC will continue to advance our knowledge of the role of this hormone in the pulmonary circulation and in other estrogen-responsive vascular beds.

\section{Acknowledgments}

We thank Marilyn Dixon for her assistance in preparing this manuscript.

This work was supported by National Institutes of Health grants HL-53546 and HD30276. The project was supported in part by the Lowe Foundation, and was done during an Established Investigatorship of the American Heart Association (P.W. Shaul).

\section{References}

1. Leffler, C.W., and J.R. Hessler. 1979. Pulmonary and systemic vascular effects of exogenous prostaglandin I2 in fetal lambs. Eur. J. Pharmacol. 54:37-42.
2. Lock, J.E., P.M. Olley, S. Soldin, and F. Coceani. 1980. Indomethacininduced pulmonary vasoconstriction in the conscious newborn lamb. Am. J. Physiol. 238:H639-H651.

3. Meyrick, B., M.E. Niedermeyer, M.L. Ogletree, and K.L. Brigham. 1985. Pulmonary hypertension and increased vasoreactivity caused by repeated indomethacin in sheep. J. Appl. Physiol. 59:443-452.

4. Acceregui, M.J., J.M. Snyder, M.D. Mitchell, and C.R. Mendelson. 1990. Prostaglandins regulate surfactant protein A (SP-A) gene expression in human fetal lung in vitro. Endocrinology. 127:1105-1113.

5. Brannon, T.S., A.J. North, L.B. Wells, and P.W. Shaul. 1994. Prostacyclin synthesis in ovine pulmonary artery is developmentally regulated by changes in cyclooxygenase-1 gene expression. J. Clin. Invest. 93:2230-2235.

6. Printz, M.P., R.A. Skidgel, and W.F. Friedman. 1984. Studies of pulmonary prostaglandin biosynthetic and catabolic enzymes as factors in ductus arteriosus patency and closure. Evidence for a shift in products with gestational age. Pediatr. Res. 18:19-24.

7. Pace-Asciak, C.R. 1977. Prostaglandin biosynthesis and catabolism in the developing sheep lung. Prostaglandins. 13:649-660.

8. Powell, W.S., and S. Solomon. 1978. Biosynthesis of prostaglandins and thromboxane $\mathrm{A}_{2}$ by fetal lung homogenates. Prostaglandins. 15:351-365.

9. Carnegie, J.A., and H.A. Robertson. 1978. Conjugated and unconjugated estrogens in fetal and maternal fluids of the pregnant ewe: a possible role for estrone sulfate during early pregnancy. Biol. Reprod. 19:202-211.

10. Gelly, C., C. Sumida, A. Gulino, and J.R. Pasqualini. 1981. Concentrations of oestradiol and oestrone in plasma, uterus and other tissues of fetal guinea pigs: their relationship to uptake and specific binding of $\left[{ }^{3} \mathrm{H}\right]$ oestradiol. J. Endocrinol. 89:71-77.

11. Robertson, H.A., R.J. Dwyer, and G.J. King. 1985. Oestrogens in fetal and maternal fluids throughout pregnancy in the pig and comparisons with the ewe and cow. J. Endocrinol. 106:355-360.

12. Seillen, C., C. Ody, F. Russo-Marie, and D. Duval. 1983. Differential effects of sex steroids on prostaglandin secretion by male and female cultured piglet endothelial cells. Prostaglandins. 26:3-12.

13. Chang, W.C., J. Nakao, H. Orimo, and S.I. Murota. 1980. Stimulation of prostacyclin biosynthetic activity by estradiol in rat aortic smooth muscle cells in culture. Biochim. Biophys. Acta. 619:107-118.

14. North, A.J., T.S. Brannon, L.B. Wells, W.B. Campbell, and P.W. Shaul. 1994. Hypoxia stimulates prostacyclin synthesis in newborn pulmonary artery endothelium by increasing cyclooxygenase-1 protein. Circ. Res. 75:33-40.

15. Darbre, P., J. Yates, S. Curtis, and R.J.B. King. 1983. Effect of estradiol on human breast cancer cells in culture. Cancer Res. 43:349-354.

16. North, A.J., R.A. Star, T.S. Brannon, K. Ujiie, L.B. Wells, C.J. Lowenstein, S.H. Snyder, and P.W. Shaul. 1994. Nitric oxide synthase type I and type III gene expression are developmentally regulated in rat lung. Am. J. Physiol. 266:L635-L641.

17. Merlie, J.P., D. Fagan, J. Mudd, and P. Needleman. 1988. Isolation and characterization of the complementary DNA for sheep seminal vesicle prostaglandin endoperoxide synthase (cyclooxygenase). J. Biol. Chem. 263:3550-3553.

18. Schwartz, G.J., B.J. Zavilowitz, A.D. Radice, A. Garcia-Perez, and J.M. Sands. 1992. Maturation of aldose reductase expression in the neonatal rat inner medulla. J. Clin. Invest. 90:1275-1283.

19. Shaul, P.W., A.J. North, T.S. Brannon, K. Ujiie, L.B. Wells, P.A. Nisen, C.J. Lowenstein, S.H. Snyder, and R.A. Star. 1995. Prolonged in vivo hypoxia enhances nitric oxide synthase type I and type III gene expression in adult rat lung. Am. J. Respir. Cell. Mol. Biol. 13:167-174.

20. Mendelsohn, M.E., and R.H. Karas. 1994. Estrogen and the blood vessel wall. Curr. Opin. Cardiol. 9:619-626.

21. Mosselman, S., J. Polman, and R. Dijkema. 1996. Erb: identification and characterization of a novel human estrogen receptor. FEBS Lett. 392:49-53.

22. Kuiper, G.G.J.M., E. Enmark, M. Pelto-Huikko, S. Nilsson, and J.A. Gustafsson. 1996. Cloning of a novel estrogen receptor expressed in rat prostate and ovary. Proc. Natl. Acad. Sci. USA. 93:5925-5930.

23. Smith, W.L. 1986. Prostaglandin biosynthesis and its compartmentation in vascular smooth muscle and endothelial cells. Annu. Rev. Physiol. 48:251-262.

24. Frangos, J.A., S.G. Eskin, L.V. McIntire, and C.L. Ives. 1985. Flow effects on prostacyclin production by cultured human endothelial cells. Science. 227:1477-1479.

25. Magness, R.R., M.D. Mitchell, and C.R. Rosenfeld. 1990. Uteroplacental production of eicosanoids in ovine pregnancy. Prostaglandins. 39:75-88.

26. Myers, S.I., R.H. Turnage, L. Bartula, B. Kalley, and Y. Meng. 1996. Estrogen increases male rat aortic endothelial cell (RAEC) PGI2 release. Prostaglandins. Leukot. Essent. Fatty Acids. 54:403-409.

27. Kuiper, G.G.J.M., B. Carlsson, K. Grandien, E. Enmark, J. Häggblad, S. Nilsson, and J.A. Gustafsson. 1997. Comparison of the ligand binding specificity and transcript tissue distribution of estrogen receptors $\alpha$ and $\beta$. Endocrinology. 138:863-870.

28. Xu, X.-M., J.-L.Tang, X. Chen, L.-H. Wang, and K.K.-Y. Wu. 1997. Involvement of two Sp1 elements in basal endothelial prostaglandin H synthase-1 promoter activity. J. Biol. Chem. 272:6943-6950.

29. Wang, L.-H., A. Hajibeigi, X.-M. Xu, D. Loose-Mitchell, and K.K.-Y. Wu. 1993. Characterization of the promoter of human prostaglandin H synthase-1 gene. Biochem. Biophys. Res. Commun. 190:406-411. 
30. O'Hagan, R.C., R.G. Tozer, M. Symons, F. McCormick, and J.A. Hassell. 1996. The activity of the Ets transcription factor PEA3 is regulated by two distinct MAPK cascades. Oncogene. 13:1323-1333.

31. Migliaccio, A., M. Di Domenico, G. Castoria, A. de Falco, P. Bontemp, E. Nola, and F. Auricchio. 1996. Tyrosine kinase/p21 $1^{\text {ras }} /$ MAP-kinase pathway activation by estradiol-receptor complex in MCF-7 cells. EMBO J. 15:12921300.

32. Fujimoto, J., S. Ichigo, M. Hori, S. Morishita, and T. Tamaya. 1995. Estrogen induces c-Ha-ras expression via activation of tyrosine kinase in uterine endometrial fibroblasts and cancer cells. J. Steroid Biochem. Mol. Biol. 55:25-33.

33. Kato, S., L. Tora, J. Yamauchi, S. Masushige, M. Bellard, and P. Chambon. 1992. A far upstream estrogen response element of the ovalbumin gene contains several half palindromic $5^{\prime}$-TGACC-3' motifs acting synergistically. Cell. 68:731-742.

34. L'Horset, F., C. Blin, S. Colnot, M. Lambert, M. Thomasset, and C. Perret. 1994. Calbindin-D9k gene expression in the uterus: study of two messenger ribonucleic acid species and analysis of an imperfect estrogen responsive element. Endocrinology. 134:11-18.

35. Murdoch, F.E., L.M. Byrne, E.A. Anazi, D.J. Furlow, D.A. Meier, and J. Gorski. 1995. Estrogen receptor binding to DNA: affinity for nonpalindromic elements from the rat prolactin gene. Biochemistry. 34:9144-9150.

36. Rabinovitch, M., W.J. Gamble, O.S. Miettinen, and L. Reid. 1981. Age and sex influence on pulmonary hypertension of chronic hypoxia and on recovery. Am. J. Physiol. 240:H62-H72.

37. Gravett, M.G., G.J. Haluska, M.J. Cook, and M.J. Novey. 1996. Fetal and maternal endocrine responses to experimental intrauterine infection in rhesus monkeys. Am. J. Obstet. Gynecol. 174:1725-1733.

38. Barnhart, B.J., C.V. Carlson, and J.W. Reynolds. 1980. Adrenal cortical function in the postmature fetus and newborn infant. Pediatr. Res. 14:13671369.

39. Magness, R.R., C.R. Rosenfeld, A. Hassan, and P.W. Shaul. 1996. Endothelial vasodilator production by uterine and systemic arteries. I. Effects of ANG II on $\mathrm{PGI}_{2}$ and NO in pregnancy. Am. J. Physiol. 270:H1914-H1923.

40. Moonen, P., G. Klok, and M.J.N.C. Keirse. 1984. Increase in concentrations of prostaglandin endoperoxide synthase and prostacyclin synthase in human myometrium in late pregnancy. Prostaglandins. 28:309-321.

41. Barrett-Connor, E., and T.L. Bush. 1991. Estrogen and coronary heart disease in women. J. Am. Med. Assoc. 265:1861-1867.

42. Bush, T.L., E. Barrett-Connor, L.D. Cowan, M.H. Criqui, R.B. Wallace, C.M. Suchindran, H.A. Tyroler, and B.M. Rifkind. 1987. Cardiovascular mortality and noncontraceptive use of estrogen in women: results from the lipid research clinics program follow up study. Circulation. 75:1102-1109.

43. Steinleitner, A., F.Z. Stanczyk, J.H. Levin, G. dÆAblaing III, M.A. Vijod, V.L. Shahbazian, and R.A. Lobo. 1989. Decreased in vitro production of 6-keto-prostaglandin $\mathrm{F}_{1 \alpha}$ by uterine arteries from postmenopausal women. Am. J. Obstet. Gynecol. 161:1677-1681.

44. Weis, H.J., and V.T. Turitto. 1979. Prostacyclin (prostaglandin $\mathrm{I}_{2}, \mathrm{PGI}_{2}$ ) inhibits platelet adhesion and thrombus formation on subendothelium. Blood. $53: 244-250$. 